\title{
Tanggung jawab Penggembalaan berdasarkan Perspektif 1 Petrus 5:1-4
}

\author{
Sara L. Sapan \& Dicky Dominggus
}

\begin{abstract}
Abstrak
Artikel ini membahas tanggung jawab penatua dalam kaitannya dengan penggembalaan terhadap jemaat Tuhan berdasarkan perspektif 1 Petrus 5:1-4. Secara umum, tanggung jawab gembala adalah memelihara jemaat Tuhan dalam hal kerohanian. Namun secara khusus Petrus memberikan deskripsi tanggung jawab tersebut secara terperinci sebagai tugas yang dilakukan tanpa dengan paksa melainkan dengan sukarela, tanpa mencari keuntungan diri sendiri melainkan dengan semangat dan tanpa menggunakan kekuasaan melainkan menjadi teladan. Artikel ini bertujuan untuk memberikan pemahaman tentang tanggung jawab penggembalaan dalam perspektif 1 Petrus 5:1-4 dan menemukan implikasinya bagi penggembalan pada masa kini. Metode yang digunakan penelitian ini merupakan metode kualitatif dengan pendekatan Historical Gramatical. Adapun tanggung jawab gembala di dalam 1 Petrus 5:1-4 adalah melayani tanpa dengan terpaksa, melayani dengan sukarela, melayani tanpa mencari keuntungan pribadi, melayani dengan semangat dan melayani dengan memberi teladan.
\end{abstract}

Kata Kunci: Tanggung Jawab; Penggembalaan; 1 Petrus 5:1-4

\begin{abstract}
This article discusses pastoral responsibilities from the perspective of 1 Peter 5: 1-4. In general, the pastor's responsibility is to care for God's church in spirituality. But specifically Peter wrote the pastor's responsibilities such as not by force but by volunteering, not looking for one's own benefit but with enthusiasm and not using power but to be an example. This article aims to understand pastoral responsibility in the perspective of 1 Peter 5: 1-4 and find its implications for pastoral today. The method used in this study is a qualitative method with a Historical Gramatical approach. The shepherd's responsibility in 1 Peter 5: 1-4 is to serve not by force, to serve voluntarily, to serve without seeking personal gain, to serve with enthusiasm and to serve by example.
\end{abstract}

Keyword: Responsiblity; Pastoral; 1 Peter 5:1-4

\section{Pendahuluan}

Sejarah kehidupan jemaat telah membuktikan bahwa jabatan penatua memiliki peranan penting dalam kehidupan jemaat, yaitu sebagai pelayan dan gembala warga 
jemaat. Sebagai pelayan warga jemaat, penatua memiliki tanggung jawab melaksanakan rupa-rupa pelayanan gerejawi seperti pemberitaan firman, pemberian pengajaran, pelayanan baptisan, perayaan perjamuan kudus dan pelaanan diakonia. Sedangkan sebagai gembala warga jemaat, penatua mempunyai tugas memberikanpimpinan kepada warga jemaat untuk memeliharan kehidupan dan keselamatan mereka. Namun demikian, sebagian besar penatua gagal dalam melaksanakan tugas dan tanggung jawabnya. Ada banyak penatua yang belum sepenuhnya menyadari akan tugas dan tanggung jawabnya sehubungan dengan jabatan sebagai pelayan dan gembala warga jemaat. Sesungguhnya, penatua merupakan jabatan yang ditetapkan untuk mengatur rumah Allah dan orang yang ditunjuk harus tidak bercacat (Titus 1:7, 1 Timotius 3:1).207

Surat 1 Petrus secara umum berbicara banyak mengenai penderitan. Namun, di akhir suratnya Petrus juga menyinggung masalah kepemimpinan penatua. Bagi Howard Marshall, secara tersirat teks 1 Petrus 5:1-4 bukan hanya berbicara tentang apa yang menjadi tugas pemimpin tetapi juga bagaimana cara memimpin jemaat.208 Pendapat Marshall menunjukkan betapa pentingnya bagi sesama penatua tidak hanya memperhatikan tanggung jawabnya sekaligus cara pelaksanaannya. Alan M. Stibb berpendapat bahwa teks 1 Petrus 5:1-4 dituliskan kepada penatua sebagai penanggung jawab jemaat. Baginya, ketika seorang penatua menjalankan tanggung jawab pada saat yang sama juga ia perlu memperhatikan alasan, motivasi dan cara yang benar. ${ }^{209}$

\footnotetext{
${ }^{207}$ Dessy Handayani, "Isu-Isu Kontemporer Dalam Jabatan Gerejawi,” Kurios 3, no. 1 (February 11, 2018): 71.

${ }^{208}$ I Howard Marshall, Peter. The IVP New Testament Commentary Series (Leicester: Inter-Varsity, 1990), 158

${ }^{209}$ Alan Marshall Stibbs, The First Epistle General of Peter: A Commentary, vol. 17 (Tyndale Press, 1959), 164.
} 
Pendapat Stibbs menunjukkan bahwa dibalik tanggung jawab penatua terdapat berbagai hal yang perlu mendapat perhatian khusus.

Meskipun menyinggung tanggung jawab penatua, teks 1 Petrus 5:1-4 merupakan teks yang membingungkan. Hal ini disebabkan karena struktur surat yang lebih dominan berbicara mengenai penderitaan, Petrus menyisipkan tulisan mengenai tanggung jawab pelayanan. Apakah maksud dari Petrus seperti itu hingga suratnya terlihat "aneh"? Dennis E. Johnson mengatasi masalah ini dengan melihat dari sisi kronologi terjadinya penghakiman. Menurutnya, penghakiman akan bermula dari gereja dan dimulai dari pemimpin. ${ }^{210}$ Jika demikian, para penatua diminta tidak hanya dapat bertahan di dalam penderitaan tetapi juga menjalani tanggung jawab dengan sungguh-sungguh. Pemikiran yang sejalan dimiliki Brian Najapfour menunjukkan bahwa Petrus sedang mendorong penatua untuk tunduk di dalam segala keadaan. ${ }^{211}$ Yang dimaksud di sini adalah para penatua harus taat kepada Tuhan dalam keadaan baik maupun dalam masa penderitaan. Ketundukan tersebut dapat ditunjukkan dengan menjalankan tanggung jawab dengan sungguh-sungguh. Dengan demikian, pelaksanaan tanggung jawab dalam teks 1 Petrus 5:1-4 dapat dilihat sebagai respon tanggung jawab kepemimpinan penatua dalam jemaat yang sedang menghadapi penderitaan.

Nasihat Petrus tentang tanggung jawab penatua tidak terlepas dari konsep teologinya tentang gereja. Teologi Petrus mengenai gereja dapat dilihat dari tiga sisi yakni struktural, organisasi dan tanggung jawab. Secara struktural, Petrus mempercayai gereja dipimpin oleh penatua. ${ }^{212}$ Dari sisi organisasi, Petrus menekankan wewenang yang dimiliki penatua dalam mengatur gereja. Penatua merupakan

${ }^{210}$ Dennis E Johnson, "Fire in God's House: Imagery from Malachi 3 in Peter's Theology of Suffering (1 Pet 4: 12-19)," Journal of the Evangelical Theological Society 29 (1986): 292.

${ }^{211}$ Brian Najapfour, "Significance Of Suffering In The Study Of First Peter," Puritan Reformed Journal (2009): 31.

212 George Eldon Ladd, Teologi Perjanjian Baru Jilid 2 (Bandung: Kalam Hidup, 1999), 413. 
pemimpin di dalam gereja dan bertugas mengawasi perkembangan anggota jemaat ${ }^{213}$ sekaligus membimbing pertumbuhan kerohanian jemaat.

Berdasarkan teks 1 Petrus 5:1-4 apakah makna tanggung jawab penatua dalam penggembalaan? Bagaimana penerapan teks ini untuk masa kini? Dengan metode penelitian kualitatif yang menggunakan pendekatan historikal gramatikal214 ini hendak memaparkan bentuk tanggung jawab para penatua yang berdasar teks 1 Petrus 5:1-4.

\section{Analisa Surat 1 Petrus 5:1-4}

\section{Pendahuluan Perintah Kepada Penatua}

Penatua di dalam bagian ini menggunakan kata $\pi \rho \varepsilon \sigma \beta \nu \tau \varepsilon \rho o u \varsigma$ yang berarti older, ${ }^{215}$ muncul dalam Perjanjian Baru sebanyak 65 kali. J Rohde menuliskan beberapa

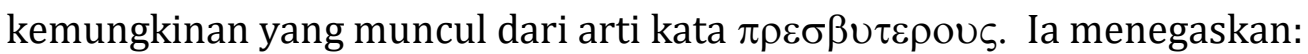

The New Testament uses $\pi \rho \varepsilon \sigma \beta \nu \tau \varepsilon \rho \circ \mathrm{s}$ with three main and several secondary meanings. Members of the lay nobility, as opposed to high-priestly nobility among the member of Sanhedrin, elders in the Jewish synagogue comunities, Christian Congregrational elders, including member of the leadership council of the original community, leaders of Pauline Gentile mission congregations, The twenty four heavenly elders of Revelation, and simply those who are older. ${ }^{216}$

Dari pendapat Rohde, menunjukkan bahwa penatua di dalam Perjanjian Baru lebih mengarah kepada orang-orang tua dari segi usia.

${ }^{213}$ Marshall, Peter. The IVP New Testament Commentary Serie, 158.

${ }^{214}$ Walter A Elwell, Baker's Evangelical Dictionary of Biblical Theology (Grand Rapids Michigan: Carlisle, Cumbria, Bakker Pub, 1996), 217. Historikal gramatikal merupakan metode yang berhubungan dengan sejarah tata bahasa atau kritik mengenai tatabahasa, yang merupakan bagian dari penafsiran Alkitab yang berusaha untuk menemukan arti mula-mula dari sebuah teks.

${ }^{215}$ Gerhard M Schneider, Exegetical Dictionary of the New Testament, vol. 2 (Wm. B. Eerdmans Publishing, 2004).

${ }^{216}$ Ibid. 
Di dalam Perjanjian Lama, kata penatua adalah Zaqen yang berarti tua. ${ }^{217}$ Dalam keseluruhan Perjanjian Lama, kata ini muncul sebanyak 178 kali mengarah kepada orang yang sudah tua baik pria maupun wanita. ${ }^{218}$ Mengapa Perjanjian Lama memandang penatua dari segi usia? Conner menjawab masalah ini dengan melihat usia seorang penatua berbanding lurus dengan kebijaksanaan dan pengalaman. Ia menegaskan:

Penatua dalam Perjanjian Lama merujuk kepada orang yang lebih tua atau sudah tua, baik pria maupun wanita. Kata penatua tidak berbicara tentang orang muda, orang baru dalam hal kebijaksanaan dan pengalaman pada umumnya datang seiring dengan waktu. ${ }^{219}$

Dengan demikian, konsep penatua dalam Perjanjian Lama lebih menekankan kepada sisi usia yang secara otomatis menyangkut pengalaman dan kebijaksanaan.

Dalam Perjanjian Lama dan Perjanjian Baru, penatua lebih menekankan pada usia seseorang. Namun pertanyaannya apakah usia seseorang mutlak menjadi standar utama untuk menjadi penatua? Howard Marshall berpendapat penatua secara sederhana berarti orang yang tua, namun di sisi lain juga berarti pemimpin anggota gereja atau pemimpin gereja. ${ }^{220}$

Howard L. Bixby menjelaskan dalam tulisannya yang berjudul “What is An Elder?"

Peter writing in the Greek language, instructs elders to be good bishops as they pastor their people. The fact that Jesus Christ is referred to as the "chief Shepherd" (pastor) in verse four is a good refutation of the idea that the role and office of pastor has no place leading the NT church. If a "chief Shepherd" is mentioned, there must also have been "undershepherds" (pastors). ${ }^{221}$

${ }^{217}$ Gerhart Johannes Botterweck, Helmer Ringgren, and Heinz-Josef Fabry, Theological Dictionary of the Old Testament: Vol. 1 (Eerdmans, 1974).

218 Ibid.

${ }^{219}$ Kevin J Conner, “Jemaat Dalam Perjanjian Baru,” (Malang: Gandum Mas, 2004), 237.

${ }^{220}$ Marshall, Peter. The IVP New Testament Commentary Series, 159.

${ }^{221}$ Howard L Bixby, "What Is an Elder?," The Journal of Ministry (Fall 2005) (2005): 5. 
Bixby tidak lagi mempersoalkan usia sebagai poin dalam kepemimpinan melainkan keseriusan dari para pemimpin dengan menjadikan Yesus sebagai contoh panutan yang perlu diteladani.

Jemaat pada masa Perjanjian Baru dipimpin oleh Penatua dan Penilik Jemaat (1Timotius 3:1-7). Kata "Penatua" dan "Penilik" adalah jabatan yang sama (Kisah Para Rasul 20:17, 28). Kata "Penilik Jemaat" sering diartikan sebagai "Pengawas" (lihat 1 Petrus 5:2 dan perhatikan bahwa jabatan ini dihubungkan dengan Kristus dalam 1 Petrus 2:25). "Penatua Jemaat" menunjuk kepada kematangan pejabat itu, sedangkan "Penilik Jemaat" menunjuk kepada tanggung jawab jabatan. Kata "gembala" adalah nama lain untuk jabatan yang sama (Efesus 4:11). Para penatua ditetapkan bagi jemaat (Kisah Para Rasul 14:23).

Peter H. Davids melihat dari sisi yang berbeda yakni pengalaman pelayanan. Baginya, penatua merupakan seorang yang senior dalam memimpin komunitas yakni jemaat. $^{222}$ Senior yang dimaksudkan Davids di sini lebih mengarah kepada sisi pengalaman pelayanan penatua. Namun, pendapat Davids pun tidak sepenuhnya benar. Hal ini didasari oleh akan munculnya rasa kurang menghargai terhadap penatua yang berusia muda sekalipun sudah matang dalam pengalaman.

Jika demikian, apakah penatua lebih condong ke sisi usia atau sisi pengalaman pelayanan? Usia dan pengalaman pelayanan seseorang penatua merupakan dua sisi mata uang. Norman Hillyer menuliskan "The term elders can indicate those senior in age or as here, senior in experience. In the nature of the case, of course, the latter meaning will

${ }^{222}$ Peter H Davids, The First Epistle of Peter, vol. 21 (Wm. B. Eerdmans Publishing, 1990), 175. 
often include the former."223 Pendapat Hillyer menunjukkan bahwa perlu adanya keseimbangan di antara usia dan pengalaman pelayanan.

Di dalam teologinya, Petrus memahami gereja dipimpin dan diatur oleh penatua. ${ }^{224}$ Dari pemahaman Petrus dapat dilihat bahwa penatua menjalankan peranan penting dalam perkembangan gereja. Ladd menuliskan penatua bertugas menggembalakan jemaat dalam disiplin dan doktrin. ${ }^{225}$ Dari pendapat Ladd dapat dilihat bahwa tugas penatua tidak sekedar memimpin namun juga perlu memperhatikan aturan main yang ada.

Petrus menggunakan kata $\sigma u \mu \pi \rho \varepsilon \sigma \beta u \tau \varepsilon \rho \circ \varsigma$ yang berarti sesama penatua. ${ }^{226}$ Kata ini muncul satu kali di Perjanjian Baru dan mengarah pada teman penatua. ${ }^{227}$ Apakah maksud dari Petrus menuliskan bagian ini? Apakah memang Petrus pada waktu itu juga merupakan penatua di dalam jemaat atau tulisan ini hanyalah sebuah "umpan cantik" yang digunakan Petrus untuk untuk mendapat respon dari penatua yang ada? Norman Hillyer menuliskan "Peter's uses of the term fellow elder is probably intended to convey that he too consider himself to be a pastor; thus he can speak from experience and with a sympathetic understanding of their responsibilities."228 Dari pendapat Hillyer dapat dilihat bahwa Petrus sedang menjelaskan posisinya juga sebagai penatua dan juga memakai pengalamannya untuk mendorong para penatua.

Scot Mc. Knight melihat frase sesama penatua sebagai bukti rasa sepenangungan Petrus. Rasa sepenanggungan tersebut ditunjukkan dengan menuliskan godaan yang 2011), 138

${ }^{223}$ Norman Hillyer, 1 \& 2 Peter, Jude (Understanding the Bible Commentary Series) (Baker Books,

${ }^{224}$ Georg Strecker, History of New Testament Literature (Trinity PressIntl, 1997), 638.

${ }^{225}$ Ladd, Teologi Perjanjian Baru Jilid 2, 413.

${ }^{226}$ A Kretzer, “Ämlho $\div \mathrm{Klj} \wedge$ F," Translated by Virgil P. Howard. In Exegetical Dictionary of the New Testament 1 (n.d.): 133-134.

${ }^{227}$ Gerhard Kittel, Gerhard Friedrich, and G W Bromiley, "Theological Dictionary of the New Testament (TDNT)," ET G Bromiley: Grand Rapids, Eerdmans (1964).

${ }^{228}$ Hillyer, 1 \& 2 Peter, Jude (Understanding the Bible Commentary Series), 138. 
akan dihadapi penatua dalam pasal 5:2-3.229 Tidak hanya itu, Petrus juga mendorong agar mereka dapat mengerti dan mengatasi godaan tersebut. Jadi, frase sesama penatua merupakan ekspresi sepenanggungan Petrus kepada penatua agar tidak terjebak dalam godaan.

\section{Tanggung Jawab Penggembalaan}

Bagian ini merupakan perintah Petrus kepada penatua. Petrus menggunakan kata perintah gembalakanlah dari kata Yunani $\pi 01 \mu \alpha v \alpha \tau \varepsilon$ yang berasal dari kata dasar $\pi$ oı $\mu \alpha \imath \omega \omega$ yang berarti memelihara. ${ }^{230}$ Kata $\pi \circ \mu \alpha v \alpha \tau \varepsilon$ termasuk dalam bentuk aorist imperatif aktif ${ }^{231}$ yang berarti sebuah perintah untuk kasus yang lebih khusus. ${ }^{232}$ Dengan demikian, Petrus menggunakan kata gembalakanlah menunjuk kepada perintah khusus yang dituliskan pada bagian berikutnya.

Kata gembalakanlah yang dituliskan Petrus dipengaruhi oleh konsep gembala di dalam Perjanjian Lama dan Perjanjian Baru. Di dalam Perjanjian Lama, kata gembala secara umum memiliki arti memberi makan domba-domba. ${ }^{233}$ Namun secara metafora, gembala menggambarkan pemeliharaan Tuhan kepada bangsa Israel. ${ }^{234}$ Sedangkan di dalam Perjanjian Baru, gembala merupakan gambaran Allah dalam menjaga umatNya. ${ }^{235}$ Semua ini dapat dilihat dari peristiwa gembala mencari domba yang tersesat sebagai metafora Tuhan menyelamatkan umatnya yang terhilang. Jadi, baik

\footnotetext{
${ }^{229}$ Scott McKnight, “The NIV Application Commentary: 1 Peter,”(Grand Rapids: Zondervan, 1996), 259.

${ }^{230}$ Horst Balz and Gerhard Schneider, Exegetical Dictionary of the New Testament, vol. 3 (Grand Rapids Michigan: Wm. B. Eerdmans Publishing, 1993).

${ }^{231}$ Harold Keeling Moulton, The Analytical Greek Lexicon Revised (Zondervan, 1978).

${ }^{232}$ John William Wenham and Lynne Newell, Bahasa Yunani Koine (The Elements of New Testament Greek) (Seminari Alkitab Asia Tenggara, 1987), 78.

${ }^{233}$ Botterweck, Ringgren, and Fabry, Theological Dictionary of the Old Testament: Vol. 1.

234 Ibid.

${ }^{235}$ Horst Balz and Gerhard Schneinder, Exegetical Dictionary Of The New Testament, Jilid 3 (Grand Rapids: Eerdmans Publishing, 1994).
} 
Perjanjian Lama maupun Perjanjian Baru memiliki kesamaan terdapat kesamaan konsep gembala terutama pada tugas pokok yakni sebagai pemelihara pertumbuhan domba. Namun, jika dilihat secara metafora, konsep gembala mengarah kepada pemeliharaan Allah terhadap umatNya.

Petrus menuliskan beberapa tanggung jawab di dalam penggembalaan. Ia menuliskan tiga tanggung jawab tersebut dalam bentuk antitesis. Hal ini dapat dilihat dari bentuknya di mana terdapat sebuah larangan kemudian diikuti penghubung tetapi dan diikuti oleh perintah yang sesungguhnya. ${ }^{236}$

\section{Tanpa Paksaan Melainkan Dengan Sukarela}

Perintah ini merupakan bagian dari perintah umum yang dituliskan Petrus, yakni menggembalakan kawanan domba Allah. Petrus menuliskan memelihara tidak dengan paksa dengan maksud setiap penatua memiliki kebebasan dalam mengambil keputusan dan kehendak namun cara yang diambil harus tetap diperhatikan. ${ }^{237}$ Maksudnya di sini adalah kebebasan yang dimiliki penatua dalam mengambil keputusan harus diimbangi oleh pertimbangan yang matang.

Petrus menuliskan perintah ini sebagai bagian dari perintah gembalakanlah. Perintah gembalakan yang dituliskan Petrus memiliki kesamaan dengan yang Yesus katakan kepada dirinya di dalam Yohanes 21:15-17. Wayne Grudem menuliskan "He verb Peter uses is the same one Jesus used when he said to Peter."238 Kesamaan yang dimaksudkan Grudem tidak hanya mencakup kata yang dipakai tetapi juga makna dibaliknya. Di dalam Yohanes 21:15-17 terdapat dua macam kata gembalakanlah yakni

\footnotetext{
${ }^{236}$ Tiga antitesis yang di maksudkan: pertama, peliharalah tidak dengan paksa tetapi dengan sukarela. Kedua, bukan untuk keuntungan diri sendiri tetapi dengan semangat. Ketiga, jangan menjalankan kekuasaan atas mereka yang dipercayakan kepadamu tetapi jadilah teladan.

${ }^{237}$ Schneider, Exegetical Dictionary of the New Testament, vol. 2.

${ }^{238}$ Wayne A Grudem, "Peter: An Introduction and Commentary" (Grand Rapids Michigan: Tyndale New Testament Commentaries, 1996), 187.
} 


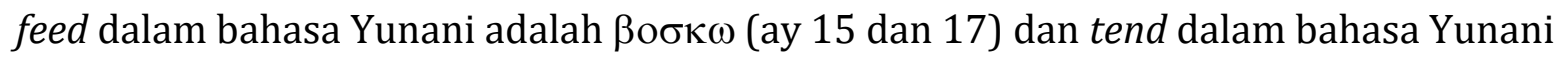

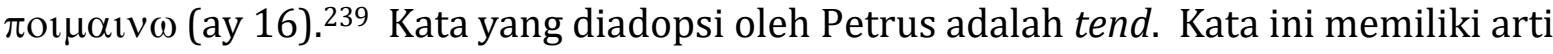
memelihara sebagai bentuk perawatan yang diberikan seorang gembala kepada dombadombanya. ${ }^{240}$ Dengan demikian, gembalakanlah yang dimaksudkan Petrus lebih berbicara pemeliharaan seorang gembala kepada dombanya.

Perintah gembalakan yang dituliskan oleh Petrus berkaitan erat dengan posisi Gembala Agung di ayat 4. Gembala agung di dalam Perjanjian Baru muncul 1 kali dan tidak mengalami variasi makna. Secara implisit, gembala agung dapat mengarah kepada pimpinan tertinggi seorang gembala yaitu Yesus. Graves menuliskan cara Petrus berbicara tentang Gembala agung menyatakan bahwa para penatua tersebut adalah gembala-gembala bawahan. ${ }^{241}$ Pandangan yang sejalan diungkapkan Marshall meskipun ia melihat frase gembala agung sebagai sebuah metafora. Marshall menuliskan "He speaks of Christ as the Chief Shepherd to whom the under shepherds are responsible."242 Pernyataan Marshall menunjukkan gembala agung akan menerima pertanggung jawaban dari gembala bawahan.

Petrus memberikan jawaban atas situasi ini dengan sikap sukarela. Sukarela dalam bahasa Yunani adalah $\varepsilon \kappa o v ı \omega \varsigma$ yang berarti dengan sukarela. ${ }^{243}$ Kata muncul di dalam Perjanjian Baru sebanyak 2 kali (Ibr 10:26 dan 1 Pet 5:2) dan memiliki arti sengaja. ${ }^{244}$ Sukarela dalam pemaham Petrus adalah mengerjakan setiap tanggung jawab dengan tulus dan sungguh-sungguh. Grudem menuliskan "Not by constraint but

${ }^{239}$ R. V. G Tasker, The Gospel According to St John: Tyndale New Testament Commentaries (Grand Rapids Michigan: Williams B. Eerdmans Publshing Company, 1981), 232.

240 Merrill C Tenney, Injil Iman: Suatu Telaah Naskah Injil Yohanes Secara Analitis (Malang: Gandum Mas, 1996), 285.

${ }^{241}$ Arthur Graves, Pertama Dan Kedua Petrus (Malang: Gandum Mas, 1982), 62.

${ }^{242}$ Marshall, Peter. The IVP New Testament Commentary Series, 164.

${ }^{243}$ Schneider, Exegetical Dictionary of the New Testament, vol. 2, p. .

${ }^{244}$ Ibid. 
willingly means not doing the job simply out of obligation or because someone has to do it. ${ }^{\prime 245}$

Sikap sukarela sangat diperlukan bagi seorang penatua. Dengan memiliki sikap sukarela maka seseorang akan menjalankan tugasnya dengan sungguh-sungguh dan maksimal. Oleh karena itu, sukarela seorang penatua harus bersumber dari dorongan hati. Ernest Best menuliskan dorongan untuk melakukan pelayanan tidak hanya berasal dari semangat sendiri tetapi juga pada kerinduan untuk mengabdi kepada Allah. ${ }^{246}$

\section{Tanpa Mencari Keuntungan Diri Sendiri Melainkan Dengan Semangat}

Selanjutnya sikap bertanggung jawab para penatua akan terlihat bila mereka terlepas dari godaan dalam hal keuangan dan loyalitas. Di dalam Perjanjian Lama, kata mengambil keuntungan dalam bahasa Ibrani adalah taavah, yang dapat berarti desire, favourite, dan greedy. ${ }^{247}$ Di dalam Perjanjian Baru, kata $\alpha 1 \sigma \chi \rho о \kappa \varepsilon \rho \delta \omega \varsigma$ hanya satu kali muncul memiliki arti keserakahan. ${ }^{248}$ Hillyer menuliskan keserakahan merupakan larangan sikap yang harus penatua jauhi. Baginya, seorang penatua merupakan orang percaya yang berkomitmen dan pendisiplinan merupakan resiko yang akan diterima. ${ }^{249}$

Petrus menuliskan semangat sebagai pencegah kejatuhan dalam masalah keuangan yaitu dengan semangat pengabdian diri. Pengabdian diri di sini memilik arti sikap kerelaan untuk menjalankan tanggung jawab dengan pengorbanan. Pengabdian diri dan pengorbanan merupakan dua hal yang tidak dapat dipisahkan kepemimpinan penatua. M Borrong menuliskan tugas utama kepemimpinan gembala adalah

${ }^{245}$ Wayne A Grudem, "Peter: An Introduction and Commentary" (Grand Rapids Michigan: Tyndale New Testament Commentaries, 1996), 188.

${ }^{246}$ Ernest Best, "I Peter and the Gospel Tradition,” New Testament Studies 16, no. 2 (1970): 170.

${ }^{247}$ Botterweck, Ringgren, and Fabry, Theological Dictionary of the Old Testament: Vol. 1.

${ }^{248}$ Schneider, Exegetical Dictionary of the New Testament, vol. 2, p. .

${ }^{249}$ Hillyer, 1 \& 2 Peter, Jude (Understanding the Bible Commentary Series), 140. 
pengorbanan dan pengabdian diri. ${ }^{250}$ Sebagai pemimpin jemaat, penatua harus dapat mengenali domba-dombanya, membela dan menjaganya dari serangan musuh serta rela berkorban. Jadi, dengan pengabdian diri penatua dapat fokus pada tanggung jawabnya dan mengorbankan kepentingan pribadinya demi kepentingan jemaat.

Petrus tidak hanya menyinggung pengabdian diri namun juga semangat dalam menjalankannya. Petrus menggunakan kata Yunani $\pi \rho 0 \theta v \mu \omega \varsigma$ yang berarti bersemangat. ${ }^{251}$ Semangat pengabdian diri dapat dipahami sebagai semangat yang dimiliki penatua dalam menjalankan tanggung jawabnya yang penuh pengabdian diri dan pengorbanan. Jika dihubungkan dengan masalah keserakahan, penatua harus melayani dengan semangat berkorban dan mengabdi meskipun tidak ada keuntungan yang diperoleh.

\section{Tanpa Menggunakan Kekuasaan Melainkan Dengan Teladan}

Pada bagian ini Petrus membahas keteladanan penatua. Petrus mengawali dengan larangan agar penatua tidak memerintah dengan menggunakaan kekuasaan.

Frase menjalankan kekuasaan berasal dari kata Yunani $\kappa \alpha \tau \alpha \kappa \nu \rho ı v o v \tau \varepsilon \varsigma$, yang berarti menundukkan. ${ }^{252}$ Kata ini termasuk dalam bentuk present participle aktif ${ }^{253}$ yang berarti sebuah pekerjaan yang dilakukan bersamaan dengan apa yang disebut oleh kata kerja dalam induk kalimat.254 Dengan demikian, frase "jangan menjalankan kekuasaan" merupakan bagian dari perintah gembalakanlah.

${ }^{250}$ Robert P. Borrong, "Kepemimpinan Dalam Gereja Sebagai Pelayanan," Voice of Wesley: Jurnal Ilmiah Musik dan Agama 2, no. 2 (November 25, 2019).

${ }^{251}$ Schneider, Exegetical Dictionary of the New Testament, vol. 2.

252 Ibid.

${ }^{253}$ Moulton, The Analytical Greek Lexicon Revised.

${ }^{254}$ Wenham and Newell, Bahasa Yunani Koine (The Elements of New Testament Greek), 135. 
Di dalam Perjanjian Lama, kata memerintah dalam bahasa Ibrani adalah radah yang memiliki arti govern dan have dominion. ${ }^{255}$ Dari beberapa arti yang ada memerintah dapat dimengerti dengan memiliki otoritas untuk mengatur dan lebih dominan dari yang lain. Kata memerintah juga terdapat pada teks Kejadian 1:26 dan 28. Pada teks tersebut, memerintah memiliki arti berkuasa atas atas segala ciptaan yang ada. ${ }^{256}$ Dengan kata lain, memerintah din sini dapat diartikan sebagai tanggung jawab dalam memelihara seluruh ciptaan.

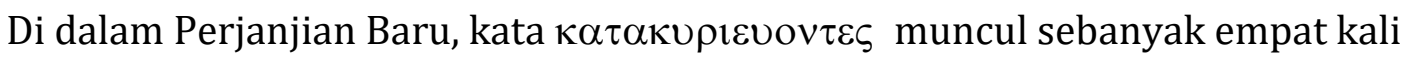
(Mat 20:25, Mrk 10:42, Kis 19:16 dan 1 Pet 5:3) dan lebih umumnya memiliki arti memerintah. ${ }^{257}$ Namun, secara khusus dalam teks 1 Petrus 5:3, frase janganlah menjalankan kekuasaan merupakan peringatan untuk para penatua supaya tidak memerintah orang-orang di gereja, tetapi harus menjadi teladan bagi mereka. Dengan demikian, frase janganlah menjalankan kekuasaan merupakan larangan yang bermula dari penyalahgunaan otoritas dalam kalangan penatua.

Sebagai pengganti melayani dengan penekanan pada seseorang yang berkuasa maka Petrus mengharuskan penatua untuk mengenakan hidup yang menjadi teladan.

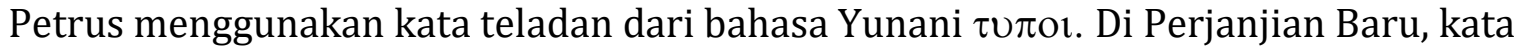
teladan muncul sebanyak 15 kali dan umumnya memiliki arti model, dan teladan. ${ }^{258}$ Mengapa Petrus menyinggung hal keteladanan hidup? Alasannya karena keteladanan hidup merupakan cara yang paling efektif di dalam pelayanan. Best menuliskan "The ideal service and readiness to suffer is the best presented not by exhortation but by example."259 Selain itu, teladan juga dapat membantu penatua tampil tanpa adanya

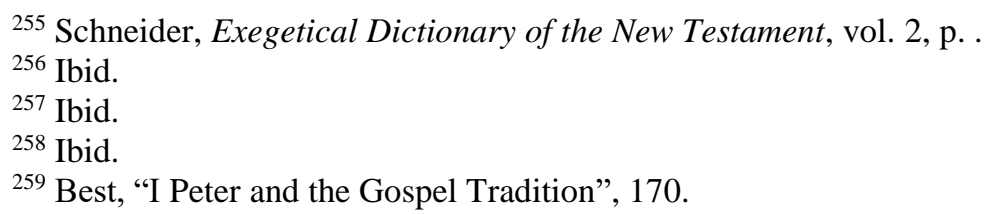


kepura-puraan. Alan M. Stibbs menuliskan dengan teladan penatua diminta menunjukkan apa adanya supaya dapat dicontoh oleh jemaat. ${ }^{260}$ Pendapat Stibbs menunjukkan bahwa keteladanan mencakup keseluruhan hidup penatua baik yang kelihatan maupun yang tidak kelihatan.

Tulisan Petrus mengenai teladan terinspiasi dari kehidupan Yesus yang telah menjadi teladan bagi orang banyak. Hal ini didasari dari pasal sebelumnya (2:18-25) ketika Petrus menuliskan penderitaan Kristus sebagai teladan. Petrus memakai kata penderitaan di dalam ayat 19-20 untuk ditujukan kepada penderitaan orang percaya, namun dalam ayat 21 dan 23 lebih mengarah kepada penderitaan yang dialami oleh Yesus. Hubungan diantara keempat pemakaian kata penderitaan ini adalah orang percaya diijinkan mengalami penderitaan badani seperti yang juga dialami oleh Yesus. Dengan demikian, bagian ini ditujukan agar orang percaya menjadikan Kristus teladan ketika mengalami penderitaan. ${ }^{261}$

Dalam penggunaannya, kata teladan yang digunakan Petrus memiliki kesamaan dengan tulisan Paulus. Paulus menggunakan kata teladan untuk menggambarkan hubungannya dengan gereja..62 Paulus menuliskan teladan dengan memakai istilah imitasi. Imitasi di sini menunjukkan kesamaan persis antara objek yang ditiru dengan pihak yang meniru. Sekalipun akan terdapat dua kesamaan, semuanya itu tidak akan menghilangkan identitas diri masing-masing. Selain itu, terdapat beberapa ayat referensi yang dipakai Paulus dan mengarah kepada teladan (1 Kor 4:16; 11:1; Flp 3:17; 4:9; 2, Tes 3:7-9, 1 Tim 4:12; Tit 2:7-8).263

\footnotetext{
${ }^{260}$ Stibbs, The First Epistle General of Peter: A Commentary, vol. 17, p. .

${ }^{261}$ Warseto Freddy Sihombing, Penderitaan Orang Percaya Dalam Surat 1 Petrus, Kerugma: Jurnal Teologi Dan Pendidikan Agama Kristen, vol. 1,( October 4, 2019): 145.

${ }^{262}$ Leonhard Goppelt, A Commentary on 1 Peter (Grand Rapids Michigan: Eerdmans Publishing Co, 1993), 347

${ }^{263}$ Grudem, "Peter: An Introduction and Commentary,” 262.
} 


\section{Upah Di Balik Tanggung Jawab Penggembalaan}

Petrus menuliskan mahkota kemuliaan sebagai upah bagi penatua. Petrus menuliskan kata mahkota yang dalam kata Yunani adalah $\sigma \tau \varepsilon \varphi \alpha v o \varsigma$. Di dalam Perjanjian baru kata $\sigma \tau \varepsilon \varphi \alpha v o \varsigma$ muncul sebanyak 18 kali dan umumnya lebih mengarah kepada hadiah dari kemenangan lomba atletik dan secara metafora berarti penghargaan yang kekal karena setia. ${ }^{264}$

Dalam sejarahnya, Mahkota di dalam Perjanjian Lama dipakai berkenaan dengan rangkaian bunga yang berbentuk lingkaran. ${ }^{265}$ Mahkota digunakan dalam acara publik seperti kalung daun yang diberikan kepada pemenang lomba Olimpiade. Sedangkan di dalam Perjanjian Baru, mahkota dituliskan sebanyak 18 kali dan secara umum mengarah kepada pemberian kepada orang percaya di akhir zaman. ${ }^{266}$ Pada masa itu, mahkota dipahami sebagai penghargaan yang diberikan Tuhan kepada orang percaya di akhir kehidupannya. Dari perbedaan yang ada dapat ditarik persamaannya bahwa mahkota merupakan reward atas jerih payah yang di lakukan.

Petrus juga menambahkan sifat dari mahkota dengan frase yang tidak dapat layu. Frase yang tidak dapat layu berasal dari kata Yunani $\alpha \mu \alpha \rho \alpha \nu \tau \imath v o v$ yang berarti unfading. 267 Petrus menggunakan kata $\alpha \mu \alpha \rho \alpha v \tau \imath v o v$ karena terinspirasi dari bunga Amarant. Clowney menuliskan: "The word translated that will never fade away is amarantinos; it is quite possible that the garland is of amaranth, a flower chosen for its everlasting quality."268 Di dalam tulisannya, Clowney sedang menjelaskan sifat bunga

\footnotetext{
${ }^{264}$ Kittel, Friedrich, and Bromiley, "Theological Dictionary of the New Testament (TDNT)."

${ }^{265}$ Schneider, Exegetical Dictionary of the New Testament, vol. 2, p. .

266 Ibid.

${ }^{267}$ Balz and Schneinder, "Exegetical Dictionary Of The New Testament, 3 Jilid Grand Rapids: Wm B."

268 Best, "I Peter and the Gospel Tradition," 207.
} 
Amarant yang tahan lama sebagai gambaran dari mahkota yang akan diberikan Gembala Agung kepada penatua.

\section{Tanggung Jawab Penggembalaan Berdasarkan Perspektif 1 Petrus 5:1-4}

\section{Melayani Tanpa Paksaan}

Petrus menuliskan melayani tanpa paksaan sebagai tanggung jawab penggembalaan. Kata paksa di dalam bahasa Yunani merupakan kata sifat yang memiliki arti keadaan terdesak, terpaksa atau dipaksa. Keterpaksaan dapat muncul karena tugas dan pekerjaan gembala yang terlalu banyak yang berakibat kelelahan sampai muncul perasaan terpaksa mengerjakan tugas pelayanan. ${ }^{269}$ Meski demikian, seorang gembala perlu menyadari bahwa tugas penggembalaan merupakan sebuah pekerjaan yang semestinya dilakukan

Masalah keterpaksaan di dalam pelayanan dapat diatasi dengan mengingat panggilan penggembalaan itu sendiri. Panggilan pelayanan bagi seorang gembala berasal dari Allah sendiri. Hal ini berarti Allah yang memanggil, Allah yang memilih, Allah yang menetapkan untuk melayani umat gembalanya di tempat masing-masing. ${ }^{270}$ Jadi, seorang gembala perlu mengingat panggilan Allah dalam pelayanannya supaya tidak melayani dengan keterpaksaan.

${ }^{269}$ Natanael S. Prajogo, "Implementasi Kepemimpinan Gembala Yang Melayani Berdasarkan 1 Petrus 5:2-10 Di Kalangan Gembala Jemaat Gereja Bethel Indonesia Se-Jawa Tengah,” Harvester: Jurnal Teologi dan Kepemimpinan Kristen 4, no. 1 (June 27, 2019): 3.

${ }^{270}$ Irwanto Sudibyo, "Pelayanan Kepemimpinan Penggembalaan Menurut Kisah Para Rasul 20: $17-$ 38,” Jurnal Teologi Gracia Deo 2, no. 1 (2019): 53. 


\section{Melayani Dengan Sukarela}

Petrus menuliskan tanggung jawab pelayanan dengan sukarela sebagai kelanjutan dari hal keterpaksaan. Sukarela dalam pemahaman Paulus adalah mengerjakan segala sesuatu dengan tulus dan sungguh-sungguh. Seorang gembala mampu melakukan pelayanannya secara sukarela karena ada kesadaran bahwa Allah yang empunya penggembalaan itu akan memberikan kemampuan dalam setiap situasi dihadapi dalam pelayanan penggembalaannya. ${ }^{271}$ Dengan demikian, seorang gembala harus harus menyadari penyertaan Allah di dalam pelayanan penggembalaannya.

Panggilan menjadi gembala bukan hal yang biasa. Karena panggilan itu datang dari Allah sendiri. Untuk itu, seorang gembala harus menjalankan tugasnya dengan sungguh-sungguh dan sukarela. Seseorang yang bekerja dengan sukarela adalah orang yang bekerja dengan kemauannya sendiri, bukan karena keterpaksaan atau juga karena kewajiban. Seseorang yang bekerja atas kehendak diri sendiri, apapun resiko yang dihadapi ia harus menerima dengan lapang dada. ${ }^{272}$

\section{Melayani Tanpa Mencari Keuntungan Pribadi}

Petrus menuliskan mencari keuntungan pribadi sebagai ancaman dalam tanggung jawab penggembalaan. Di dalam teks 1 Petrus 5:2, Petrus sedang mengingatkan para gembala bahwa tujuan utama pelayanan bukanlah untuk mencari atau keuntungan yang tidak layak. Keuntungan pribadi yang dimaksudkan di sini bukan sekedar keuntungan materi, melainkan juga keuntungan popularitas dari melacurkan

\footnotetext{
${ }^{271}$ Calvin Sholla Rupa', "Ciri Khas Seorang Gembala Berdasarkan Perspektif 1 Petrus 5:1-4,” Jurnal Jaffray 14, no. 2 (September 28, 2016): 172.

272 Yenda Kosta and Jermia Djadi, "Peranan Gembala Sebagai Pemimpin Dalam Perspektif I Petrus 5:1-4 Dan Relevansinya Pada Masa Kini,” Jurnal Jaffray 9, no. 2 (October 2, 2011): 178-179.
} 
Injil untuk menarik banyak orang menjadi jemaat. ${ }^{273}$ Dengan mencari keuntungan pribadi, maka seorang gembala tidak lagi menjadikan Kristus sebagai tujuan pelayanan, namun lebih kepada aktualisasi diri sendiri.

Mencari keuntungan pribadi merupakan hal yang sulit untuk dibedakan dengan pada umumnya. Hal ini dikarenakan tidak terlihat secara langsung. Untuk itu, perlu kejelian untuk membedakan gembala sidang yang memiliki motivasi yang murni dengan yang mencari keuntungan pribadi. Namun, pada dasarnya gembala yang tidak mengenal Allah adalah mereka yang menggunakan kepemimpinan untuk mengeruk keuntungan pribadi. ${ }^{274}$

\section{Melayani Dengan Semangat}

Semangat pelayanan merupakan hal yang perlu diperhatikan gembala di dalam pelayanan. Semangat yang dimaksudkan oleh Petrus di sini adalah antusias dan komitmen untuk setia melayani meskipun menghadapi berbagai macam resiko. Petrus menggunakan kata semangat untuk menggambarkan ekspresi antusiasme yang kuat dan hasrat untuk mengabdi kepada tugas yang diberikan. ${ }^{275}$ Seorang gembala perlu memiliki semangat dalam menjalankan tugas penggembalaannya. Hal ini terkait penggembalaan merupakan tugas yang cukup kompleks dengan berbagai resiko dan tantangan di dalamnya.

\footnotetext{
273 Prajogo, "Implementasi Kepemimpinan Gembala Yang Melayani Berdasarkan 1 Petrus 5:2-10 Di Kalangan Gembala Jemaat Gereja Bethel Indonesia Se-Jawa Tengah,: 5 .”

${ }^{274}$ Bill Lawrence, Effective Pastoring (Menggembalakan Dengan Hati) (Yogyakarta: Andi, 2009), 114.

275 Prajogo, "Implementasi Kepemimpinan Gembala Yang Melayani Berdasarkan 1 Petrus 5:2-10 Di Kalangan Gembala Jemaat Gereja Bethel Indonesia Se-Jawa Tengah,: 6.”
} 


\section{Melayani Dengan Memberi Teladan}

Petrus menyinggung keteladanan sebagai bagian dari tanggung jawab penggembalaan. Teladan yang dimaksudkan Petrus merupakan contoh melalui sifat dan karakter. Petrus sedang mengingatkan gembala untuk dapat menjadi teladan bagi jemaat melalui kehidupan mereka.

Erwin Lutzer menuliskan teladan merupakan cara yang paling efektif untuk membimbing jemaat. ${ }^{276}$ Hal ini dikarenakan teladan lebih berbicara banyak daripada nasihat. Selain itu, status gembala sebagai public figure yang membawa perubahan dalam jemaat. 277

Keteladanan meliputi berbagai macam hal. Hal senada dituliskan Paulus kepada Timotius untuk dapat menjadi teladan dalam perkataan, tingkah laku, kasih, kesucian dan kesetiaan (1 Timotius 4:12). Namun di dalam kenyataannya, banyak gembala yang gagal melaksanakan tanggung jawabnya karena tidak dapat menjadi teladan bagi jemaatnya. C.S. Rupa menuliskan bahwa kegagalan gembala menjadi teladan karena dikuasai oleh hawa nafsu. ${ }^{278}$

\section{Kesimpulan}

Tanggung jawab Penggembalaan merupakan hal yang mulia. Hal ini dikarenakan tanggung jawab menjadi gembala bersumber dari panggilan Allah. Di dalam Petrus 5:14, Petrus menuliskan tanggung jawab penggembalaan. Ada beberapa tanggung jawab yang dituliskan Petrus seperti melayani tidak dengan terpaksa, melayani dengan

\footnotetext{
${ }^{276}$ Erwin W Lutzer, Pastor to Pastor: Tackling Problems of the Pulpit (Moody Publishers, 1987).

${ }^{277}$ George Barna, The Habits of Highly Effective Churches: Being Strategic in Your God-given Ministry (Gospel Light Publications, 2000).

${ }^{278}$ Rupa', 'Ciri Khas Seorang Gembala Berdasarkan Perspektif 1 Petrus 5:1-4,: 185."
} 
sukarela, melayani tanpa mencari keuntungan pribadi, melayani dengan semangat dan melayani dengan memberi teladan. Dengan menjalankan tanggung jawab tersebut, seorang gembala akan menjadi gembala sidang yang ideal.

\section{Daftar Pustaka}

Balz, Horst, and Gerhard Schneider. Exegetical Dictionary of the New Testament. Vol. 3. Grand Rapids Michigan: Wm. B. Eerdmans Publishing, 1993.

Balz, Horst, and Gerhard Schneinder. "Exegetical Dictionary Of The New Testament, 3 Jilid Grand Rapids: Wm B.” Eerdmans Publishing Co, 1994.

Barna, George. The Habits of Highly Effective Churches: Being Strategic in Your God-given Ministry. Gospel Light Publications, 2000.

Best, Ernest. "I Peter and the Gospel Tradition." New Testament Studies 16, no. 2 (1970): 95-113.

Bixby, Howard L. "What Is an Elder?" The Journal of Ministry (Fall 2005) (2005): 5-23.

Borrong, Robert P. “KEPEMIMPINAN DALAM GEREJA SEBAGAI PELAYANAN." Voice of Wesley: Jurnal Ilmiah Musik dan Agama 2, no. 2 (November 25, 2019).

Botterweck, Gerhart Johannes, Helmer Ringgren, and Heinz-Josef Fabry. Theological Dictionary of the Old Testament: Vol. 1. Eerdmans, 1974.

Conner, Kevin J. “Jemaat Dalam Perjanjian Baru.” Malang: Gandum Mas (2004).

Davids, Peter H. The First Epistle of Peter. Vol. 21. Wm. B. Eerdmans Publishing, 1990.

Elwell, Walter A. Baker's Evangelical Dictionary of Biblical Theology. Grand Rapids Michigan: Carlisle, Cumbria, Bakker Pub, 1996.

Goppelt, Leonhard. A Commentary on 1 Peter. Grand Rapids Michigan: Eerdmans Publishing Co, 1993.

Graves, Arthur. Pertama Dan Kedua Petrus. Malang: Gandum Mas, 1982.

Grudem, Wayne A. "Peter: An Introduction and Commentary." Grand Rapids Michigan: Tyndale New Testament Commentaries, 1996.

Handayani, Dessy. "Isu-Isu Kontemporer Dalam Jabatan Gerejawi." Kurios 3, no. 1 (February 11, 2018): 66.

Hillyer, Norman. 1 \& 2 Peter, Jude (Understanding the Bible Commentary Series). Baker Books, 2011.

Johnson, Dennis E. "Fire in God's House: Imagery from Malachi 3 in Peter's Theology of Suffering (1 Pet 4: 12-19)." Journal of the Evangelical Theological Society 29 (1986): 285-294.

Kittel, Gerhard, Gerhard Friedrich, and G W Bromiley. "Theological Dictionary of the New Testament (TDNT)." ET G Bromiley: Grand Rapids, Eerdmans (1964). 
Kosta, Yenda, and Jermia Djadi. "Peranan Gembala Sebagai Pemimpin Dalam Perspektif I Petrus 5:1-4 Dan Relevansinya Pada Masa Kini." Jurnal Jaffray 9, no. 2 (October 2, 2011): 172. Accessed May 16, 2020. https://ojs.sttjaffray.ac.id/JJV71/article/view/100.

Kretzer, A. “Ämlho $\div \mathrm{Klj} \wedge$ F.” Translated by Virgil P. Howard. In Exegetical Dictionary of the New Testament 1 (n.d.): 133-134.

Ladd, George Eldon. Teologi Perjanjian Baru Jilid 2. Bandung: Kalam Hidup, 1999.

Lawrence, Bill. Effective Pastoring (Menggembalakan Dengan Hati). Yogyakarta: Andi, 2009.

Lutzer, Erwin W. Pastor to Pastor: Tackling Problems of the Pulpit. Moody Publishers, 1987.

Marshall, I Howard. Peter. The IVP New Testament Commentary Series. Leicester: Inter-Varsity, 1990.

McKnight, Scott. “The NIV Application Commentary: 1 Peter." Grand Rapids: Zondervan 120 (1996).

Moulton, Harold Keeling. The Analytical Greek Lexicon Revised. Zondervan, 1978.

Najapfour, Brian. "Significance Of Suffering In The Study Of First Peter." Puritan Reformed Journal (2009): 31.

Prajogo, Natanael S. "Implementasi Kepemimpinan Gembala Yang Melayani Berdasarkan 1 Petrus 5:2-10 Di Kalangan Gembala Jemaat Gereja Bethel Indonesia Se-Jawa Tengah." HARVESTER: Jurnal Teologi dan Kepemimpinan Kristen 4, no. 1 (June 27, 2019): 1-21.

Rupa', Calvin Sholla. "Ciri Khas Seorang Gembala Berdasarkan Perspektif 1 Petrus 5:1-4." Jurnal Jaffray 14, no. 2 (September 28, 2016): 165. Accessed May 12, 2020. https://ojs.sttjaffray.ac.id/JJV71/article/view/198.

Schneider, Gerhard M. Exegetical Dictionary of the New Testament. Vol. 2. Wm. B. Eerdmans Publishing, 2004.

Sihombing, Warseto Freddy. Penderitaan Orang Percaya Dalam Surat 1 Petrus. KERUGMA: Jurnal Teologi Dan Pendidikan Agama Kristen. Vol. 1, October 4, 2019. Accessed May 31, 2020. http://www.sttiimedan.ac.id/e-journal/index.php/kerugma.

Stibbs, Alan Marshall. The First Epistle General of Peter: A Commentary. Vol. 17. Tyndale Press, 1959.

Strecker, Georg. History of New Testament Literature. Trinity PressIntl, 1997.

Sudibyo, Irwanto. "Pelayanan Kepemimpinan Penggembalaan Menurut Kisah Para Rasul 20: 1738." Jurnal Teologi Gracia Deo 2, no. 1 (2019): 46-61.

Tasker, R. V. G. The Gospel According to St John: Tyndale New Testament Commentaries. Grand Rapids Michigan: Williams B. Eerdmans Publshing Company, 1981.

Wenham, John William, and Lynne Newell. Bahasa Yunani Koine (The Elements of New Testament Greek). Seminari Alkitab Asia Tenggara, 1987. 


\section{Tentang Penulis:}

Sara L. Sapan menyelesaikan studi pascasarjana di STT Satyabhakti, Malang. Dan kini sebagai dosen tetap di STT IBC, Batam.

Dicky Dominggus menyelesaikan studi pascasarjana di STT Satyabhakti, Malang. Dan kini sebagai dosen tetap di STT IBC, Batam, selain sebagai editor kepala Jurnal Teologi Caraka, Batam. 